\title{
Predicting solar radiation transmittance in the understory of even-aged coniferous stands in temperate forests
}

\author{
Gabriela SONOHAT $^{\mathrm{a}}$, Philippe BALANDIER ${ }^{\mathrm{a} *}$, Felix RUCHAUD $^{\mathrm{a}, \mathrm{b}}$ \\ ${ }^{a}$ Cemagref, Clermont-Ferrand Regional Centre, Team of Applied Ecology of Woodlands, 24 av. des Landais, BP 50085, 63172 Aubière Cedex, France \\ b Present address: ONF, Agence départementale de l'Allier, Les Portes d'Arvernes, rue de la République, BP 1722, 03017 Moulins Cedex, France
}

(Received 30 January 2003; accepted 3 September 2003)

\begin{abstract}
The amount of transmitted light in the understories of forest stands affects many variables such as biomass and diversity of the vegetation, tree regeneration and plant morphogenesis. Therefore, its prediction according to main tree or stand characteristics, without the need for difficult and costly light measurements, would be most useful for many different users and scientists. Transmitted global solar radiation was measured using tube solarimeters in the understories of 204 plots of even-aged coniferous stands of four species (Pseudotsuga menziesii, Picea abies, Larix sp. and Pinus sylvestris) in a wide range of ecological and management conditions in the temperate climate zone. From these data, a range of simple models based on the Beer-Lambert law was built and fitted to predict mean stand radiation transmittance from basic stand traits and management features: stand basal area, stand age, time since last thinning, and last thinning intensity. Forest managers can use it to predict understory light availability and adapt their silviculture to various objectives.
\end{abstract}

coniferous forest / solar radiation / model / basal area / stand management

Résumé - Simulation de l'éclairement relatif dans le sous-bois de peuplements réguliers de conifères en forêts tempérées. La quantité de lumière disponible dans le sous-bois des forêts affecte de nombreux processus tels que la production de biomasse et la diversité de la végétation, la régénération des arbres et la morphogénèse des plantes. Prédire cette quantité sans avoir à effectuer de mesures de lumière délicates et coûteuses serait donc d'un grand intérêt pour différents utilisateurs et chercheurs. Le rayonnement solaire global transmis a été mesuré avec des solarimètres dans le sous-bois de 204 parcelles de peuplements réguliers de quatre espèces de conifère (Pseudotsuga menziesii, Picea abies, Larix sp. et Pinus sylvestris) dans diverses conditions écologiques et de gestion en climat tempéré. A partir de ces données et en utilisant le formalisme de la loi de Beer-Lambert, plusieurs modèles ont été bâtis et ajustés simulant la transmission de l'éclairement sous couvert en fonction des caractéristiques dendrométriques simples des peuplements étudiées et de leur gestion : surface terrière et âge du peuplement, durée depuis la dernière éclaircie et intensité de celle-ci. Ces outils pourraient être facilement utilisés par les gestionnaires forestiers pour estimer le niveau d'éclairement sous couvert et ainsi adapter leur sylviculture à divers objectifs.

forêt de conifères / éclairement / modèle / surface terrière / gestion des peuplements

\section{INTRODUCTION}

Transmitted irradiance to forest understories is a crucial environmental factor governing many processes such as understory microclimate [2,22], tree regeneration, seedling and tree survival and growth $[9,31,34]$, growth of advance regeneration $[32,44]$, biomass allocation and crown morphology [38], species succession and diversity $[4,10,27]$, soil biological activity $[3,60]$, and water and mineral resource use $[1,16]$. Also, understory transmitted irradiance is a measure of the amount of solar radiation intercepted by the tree stand canopy, which is directly linked to dry biomass production (Monteith [40], and later [17, 25, 43], for example). Hence the assessment of available light in forest understories is important for a better understanding of a wide range of different processes.

Each process is associated with a specific solar wavelength domain. Photosynthetically active radiation (PAR) of wavelength between 400 and $700 \mathrm{~nm}$ controls photosynthetic processes. Plant morphogenesis is driven by the red/far red ratio $(660 / 730 \mathrm{~nm})$ or the blue-UV-A wavebands [8, 57]. Global solar radiation over the whole solar spectrum is involved in energy balance (soil surface and canopy foliage microclimate, vegetation transpiration, etc.). Wavelengths greater than $780 \mathrm{~nm}$, PAR and total solar radiation are most often measured in canopy studies, with different measuring systems and different units [7].

\footnotetext{
*Corresponding author: philippe.balandier@ cemagref.fr
} 
Forest canopies modify the flux density, spatial distribution and spectral characteristics of incident solar irradiance according to the geometric, optical and physiological properties of the canopy. For the same tree species, radiation transmission through the canopy can be very different according to stand structure. The various forest operations, particularly thinning, will modify radiation transmission, which in turn will modify tree growth and development along with other processes such as those involved in plant diversity and soil biology. As transmitted radiation directly controls fundamental processes in the forest understory, quantifying this variable is often more efficient to adapt silvicultural operations to meet different objectives [5], than the simple knowledge of basal area per se for example.

Solar radiation transmission measurement under a tree canopy is not easy and needs accurate equipment and methods, generally a large number of sensors and can be complicated by spatial and temporal variability of transmitted radiation [7, 51, 64]. Hence because of their technical complexity, reports of direct measurements of transmitted solar radiation under forest stands are scant (e.g. [45, 50, 52, 58, 59]). An easy indirect method for adequate estimation of canopy transmittance would thus be a useful tool for scientific and forest management purposes.

Numerous surrogate methods to estimate understory solar radiation transmittance have been proposed, including empirical or process-based forest light models [56]. Empirical models relate light behavior to canopy or tree characteristics such as stand density, crown closure percentage, site index [32, 35], basal area (e.g. [24, 28]), and combinations of tree size and distance $[11,30]$. These models provide a statistical measure of the influence of stand or individual tree characteristics on solar radiation interception, but have limited predictive value for ecological conditions where data are not available. Theoretically, process-based radiation models can describe and predict light regime in any forest stand (e.g., [37] for agroforestry systems), but the large amount of data required to describe canopy structure and leaf properties precludes their routine use and most of them are so complex that they are unusable for practitioners such as forest managers [51].

A practical compromise is provided by semi-empirical process-oriented models, which adjust relationships describing light behavior as a function of stand traits, based on fundamental laws for light interception in plant canopies. Most forest radiation models are included in this class, with a wide range of stand structure complexity, from even-aged homogeneous stands (e.g., [20]) to heterogeneous, mixed, uneven-aged ones (e.g., [15]). More complex models can require a large number of parameters (e.g., 30 parameters in [67]) or a large amount of data for spatially explicit or individual-based approaches (e.g., $[15,18])$. Two main assumptions are generally made: the first one assumes that geometrical and/or physiological stand/tree characteristics are synthetic indicators of environment-driven processes, and this makes it possible empirically to replace unknown ecological mechanisms by canopy trait relationships (e.g., in [49], site effects are described by a nonlinear allometric model). The second main assumption is that the light interception process is driven by canopy foliage amount, so leaf area or leaf biomass becomes a model key variable. Consequently, a preferred empirical approach is to link easy-to-measure stand characteristics to leaf area, which is difficult to measure directly.
Foliage area is thus expressed as a function of sapwood area, basal area, stem diameter, tree and crown size, etc. (e.g. [55, 66]).

Our aim was therefore (i) to assess, by direct measurements, understory radiative environment in coniferous stands of Douglas fir (Pseudotsuga menziesii (Mirbel) Franco), Norway spruce (Picea abies (L.) Karsten), larch (Larix decidua Miller, Larix $\times$ eurolepis A. Henry and Larix kaempferi (Lindley) Carrière) and Scots pine (Pinus sylvestris L.) in a wide range of ecological and management conditions in the temperate climate zone, and (ii) to propose a simple model to predict mean stand radiation transmittance, founded on basic stand traits and management features, and therefore easy to use by forest managers. As we were interested in characterizing the light environment not only for its PAR component or morphogenetic effects but also for its energy budget component, we measured global solar radiation transmittance. We also wanted to characterize mean radiation transmittance under trees at the stand level and not at a smaller scale.

\section{MATERIALS AND METHODS}

\subsection{Site and stand characteristics}

Four coniferous species, Douglas fir (Pseudotsuga menziesii (Mirbel) Franco), Norway spruce (Picea abies (L.) Karsten), larch (Larix decidua Miller, Larix $\times$ eurolepis A. Henry, and Larix kaempferi (Lindley) Carrière) and Scots pine (Pinus sylvestris L.) were studied. Light measurements were carried out in France and Belgium on a total of 46 stands in different sites; 9 for Douglas-fir, 5 for Norway spruce, 11 for larch and 21 for Scots pine. On these sites, a total of 204 plots were measured; 54, 41, 49 and 60 for Douglas fir, Norway spruce, larch and Scots pine respectively. Sites presented well-contrasted ecologi$\mathrm{cal}$, and climatologic characteristics, with latitude ranging between $45^{\circ} \mathrm{N}$ and $50^{\circ} \mathrm{N}$, and altitude between $145 \mathrm{~m}$ and $1250 \mathrm{~m}$. According to measurement dates and site latitude, solar elevation at noon ranged between $45^{\circ}$ and $68^{\circ}$. The stands also had different age and thinning histories. Stands were all even-aged and generally monospecific. None contained more than $20 \%$ of trees of other species. Analysis was thus possible by species.

Frequency distributions of main stand characteristics are shown in Figure 1, giving the validity range of this study. Stand ages ranged from 18 to 31,20 to 36,10 to 92 and 22 to 96 years for respectively Douglas fir, Norway spruce, larch and Scots pine. Only larch and Scots pine had stand ages above 50 years; 7 stands for larch (at the same age of 92 years) and 20 stands for Scots pine, i.e., a proportion of $13 \%$ of all the stands studied.

The stands were not all thinned. For stands that were thinned (42 for Douglas fir, 37 for Norway spruce, and 28 for larch, thus 107 stands in total), the time since last thinning ranged between 1 and 15 years, with a sharply decreasing frequency for the highest values. Only two old larch stands presented a value of 31 years for time since last thinning. No information on Scots pine stand thinning was available, and so pine was not included in the analysis with this variable.

Thinning intensity (expressed as ratio of basal area decrease to initial basal area) was available only for 28 Douglas fir stands, 26 Norway spruce stands and 21 larch stands. 94\% of values were grouped between 0.25 and 0.65 of the stand basal area value before thinning.

\subsection{Measurements}

\subsubsection{Light measurements}

Solar irradiation was measured under the canopy of each plot (i.e., a surface area between 500 and $1600 \mathrm{~m}^{2}$ ) using tube solarimeters of 

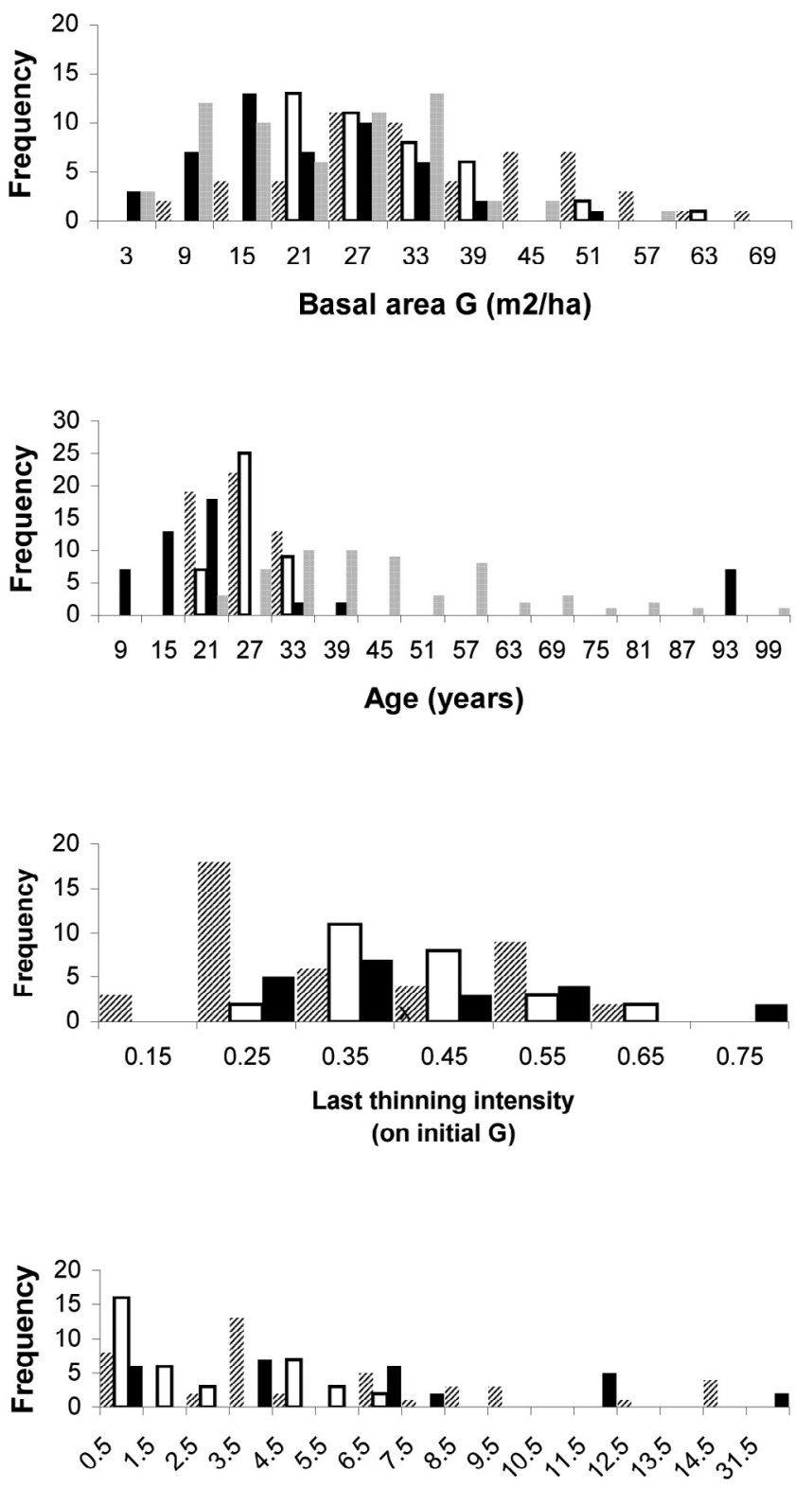

Time since the last thinning (years)

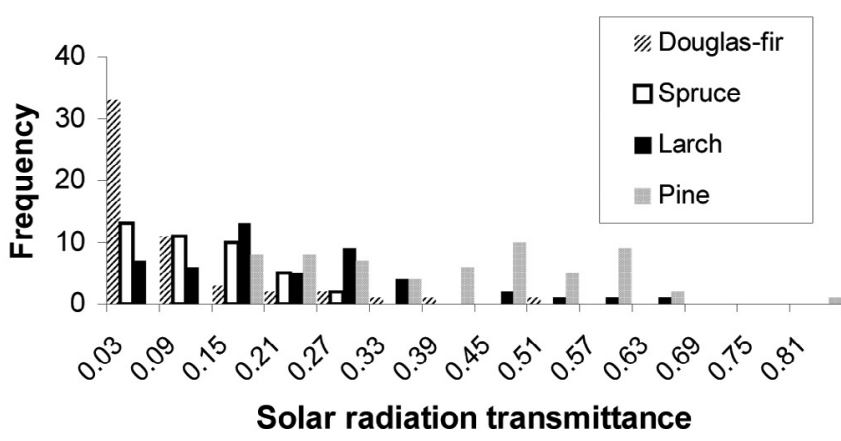

Figure 1. Frequency distributions of main stand characteristics and of measured transmittance values, by species. length $1.0 \mathrm{~m}$ (TSL tube solarimeters, Delta- $T$ devices Ltd, Burwell, UK). Tube solarimeters measure incoming short-wave radiation between 300 and $3000 \mathrm{~nm}$, which corresponds to global solar radiation. As we wanted to characterize mean irradiation under trees at the stand or part-stand level and not at a smaller scale, $1 \mathrm{~m}$ long solarimeters were more suitable than point sensors as they integrate the local variations of irradiation. Moreover, when the tree cover is rather heterogeneous, linear sensors give better results than point sensors in predicting mean irradiation [54]. In order to integrate spatial variability, which can be high (variation coefficient sometimes $>20 \%$, [6, 51]), 4 to 8 sensors were placed in different points of the same stand, and the measurements were averaged to characterize light environment under the canopy. As there was also a marked temporal variation of irradiation for the same point under the canopy during the same day (and of course during the same season, but we made measurements only during the leafy season for larch, i.e., from May to September), we measured irradiance continuously for $24 \mathrm{~h}$ in each plot. Simultaneously, two tube solarimeters were installed nearby in the open to measure daily incident global radiation, which was calculated by averaging values measured by the two instruments. Stand solar radiation transmittance $T$ was calculated as the ratio of daily transmitted solar irradiation to daily incident solar irradiation. This $T$ value obtained from measured irradiation values will hereafter be called measured transmittance. Measured solar radiation transmittance ranged respectively from 0.005 to $0.5,0.007$ to $0.3,0.03$ to 0.64 , and 0.15 to 0.81 for Douglas fir, Norway spruce, larch and Scots pine stands. $70 \%$ of transmittance data had values between 0.01 and 0.14 for Douglas fir, between 0.04 and 0.2 for Norway spruce, between 0.06 and 0.32 for larch and between 0.21 and 0.55 for Scots pine (see Fig. 1).

\subsubsection{Tree measurements and derived stand characteristics}

All the trees around the solarimeters and over a distance of about one tree height from the solarimeters were measured for their total height, stem circumference $C$ at breast height $(1.30 \mathrm{~m})$, and height of crown. Stem density $n$ and stand basal area $G$ were then calculated, as $n=N / A$ and $G=\frac{\sum_{i} C_{i}^{2}}{4 \pi A}$, where $N$ is total stem number and $A$ is the ground surface area investigated. Stand age was noted for all the stands, and information on thinning practices was collected when available. Concerning thinning characteristics, the time since last thinning $\tau$ and the thinning intensity $I$ were retained for this study. Thinning intensity $I$ is defined in terms of basal area, being equal to the ratio of absolute $G$ variation $\left(\Delta G=G_{0}-G\right)$ against initial value $G_{0}$ : $I=\Delta G / G_{0}$.

Basal area ranged from 11 to 66,18 to 62,4 to 51 and 4 to $57 \mathrm{~m}^{2} \mathrm{ha}^{-1}$ for respectively Douglas fir, Norway spruce, larch and Scots pine stands. Larch and Scots pine were characterized by a high proportion of stands with low values of basal area $\left(<20 \mathrm{~m}^{2} \mathrm{ha}^{-1}\right)$, while Douglas fir exhibited a greater frequency in the upper range of basal area values $\left(>45 \mathrm{~m}^{2} \mathrm{ha}^{-1}\right.$ ) (see Fig. 1).

\subsection{Data treatment and modeling}

Influence of diverse stand characteristics, as presented above, on solar radiation transmittance was assessed using a multiple factor regression procedure (GLM), with SAS/STAT ${ }^{\circledR}$ software [53], for independent and crossed variable combinations. For the final analysis we retained the two stand variables that showed the most obvious effect on stand transmittance for all the stands studied: basal area and stand age, together with thinning management data: time since last thinning and last thinning intensity. Simple models shaped on the Beer-Lambert law for radiation extinction were subsequently proposed 
Table I. Fitting of general linear models explaining stand transmittance by the four variables retained for this study, namely basal area $(G)$, age $(A)$, time since last thinning $(\tau)$ and thinning intensity $(I)$. Analysis is performed on the whole data set and by species, and models are classified by their adjusted $R$-square values Only basal area $G$ and age $A$ values were available for Scots pine stands.

\begin{tabular}{|c|c|c|c|c|c|c|c|c|c|}
\hline \multicolumn{2}{|c|}{ Total } & \multicolumn{2}{|c|}{ Douglas-fir } & \multicolumn{2}{|c|}{ Spruce } & \multicolumn{2}{|c|}{ Larch } & \multicolumn{2}{|c|}{ Pine } \\
\hline Model & $\operatorname{Adj}-R^{2}$ & Model & $\operatorname{Adj}-R^{2}$ & Model & $\operatorname{Adj}-R^{2}$ & Model & $\operatorname{Adj}-R^{2}$ & Model & $\operatorname{Adj}-R^{2}$ \\
\hline$G A \tau$ & 0.715 & $G \tau$ & 0.699 & GAI & 0.586 & $G A \tau I$ & 0.540 & $G A$ & 0.720 \\
\hline$G A \tau I$ & 0.714 & $G \tau I$ & 0.691 & $G A \tau I$ & 0.572 & $G A$ & 0.525 & $G$ & 0.707 \\
\hline$G \tau I$ & 0.699 & $G A \tau$ & 0.677 & $G I$ & 0.571 & $G A \tau$ & 0.517 & A & 0.001 \\
\hline$G \tau$ & 0.696 & $G A \tau I$ & 0.666 & $G \tau I$ & 0.555 & $G A I$ & 0.515 & & \\
\hline$G A I$ & 0.691 & $G$ & 0.663 & $G A$ & 0.540 & $G I$ & 0.330 & & \\
\hline$G A$ & 0.658 & $G I$ & 0.648 & $G A \tau$ & 0.528 & $A \tau I$ & 0.304 & & \\
\hline$G I$ & 0.542 & $G A$ & 0.639 & $G$ & 0.513 & $G \tau I$ & 0.293 & & \\
\hline$G$ & 0.480 & $G A I$ & 0.621 & $G \tau$ & 0.495 & $G \tau$ & 0.276 & & \\
\hline$\tau I$ & 0.155 & $\tau I$ & 0.274 & $\tau$ & 0.434 & $G$ & 0.268 & & \\
\hline$A \tau I$ & 0.152 & $A \tau I$ & 0.235 & $\tau I$ & 0.427 & $\tau I$ & 0.259 & & \\
\hline$A \tau$ & 0.141 & $I$ & 0.200 & $A \tau$ & 0.418 & $I$ & 0.244 & & \\
\hline $\mathrm{t}$ & 0.134 & $A I$ & 0.171 & $A \tau I$ & 0.407 & $A I$ & 0.202 & & \\
\hline$A$ & 0.106 & $\tau$ & 0.048 & $I$ & 0.143 & $\tau$ & 0.004 & & \\
\hline$I$ & 0.010 & A & 0.003 & A & 0.001 & A & 0.001 & & \\
\hline
\end{tabular}

to describe light behavior as a function of the factors listed above. The Beer-Lambert turbid medium approach [39] is widely used for describing radiation extinction in plant canopies, including forests (e.g., [16]). Light transmittance under a canopy is expressed as:

$$
T=e^{-k L A I}
$$

where $L A I$ is the canopy leaf area index, and $k$ is an extinction coefficient, which depends mainly on cover properties. This theoretically derived law for vegetation canopies assumes that leaves are small and randomly distributed in the canopy layer, so it can basically be used for closed homogeneous forest canopies. Deviations from this canopy pattern can be modeled by correction factors applied to extinction coefficient $k$. More generally, extinction coefficient $k$ reflects influences of all variables other than $L A I$ on light extinction in the canopy, so it can be expressed as a function of these variables instead of as a constant value in the basic relation. Assuming stand leaf area index $(L A I)$ is related to basal area $G$ by a linear unbiased relationship $L A I=a G$, the Beer-Lambert law (1) for solar radiation extinction can be re-written:

$$
T=e^{-k L A I}=e^{-k a G}=e^{-b G}
$$

where $T$ is canopy transmittance (dimensionless), $G$ stand basal area $\left(\mathrm{m}^{2} \mathrm{ha}^{-1}\right)$ and $b$ a coefficient that can be considered as a $G$-related extinction coefficient.

Our modeling approach thus consisted in adjusting certain functions to express light extinction coefficient depending on the main variables studied. Correction coefficients were successively defined through functional relationships for stand characteristics, and the resulting model improvement was tested. Model parameters were adjusted using the SAS/STAT nonlinear model (NLM) procedure [53]. To estimate model sensitivity to parameter variation, the relative variation of transmittance, $\mathrm{d} T / T$, was calculated for a parameter variation of 0.1 and typical values of model parameters. A simplified oneparameter model was finally proposed as a modeling analysis outcome. To validate this model, a bootstrap method of data random resampling was applied: on each species data set, $75 \%$ of data were used to fit model parameter, and the model was tested on the remaining $25 \%$ of data. The two sub-samples were obtained by random data sampling, and the procedure was reiterated 15 times.

\section{RESULTS}

\subsection{ANOVA results}

Table I reports multiple factor variance analysis results for the transmission coefficient as influenced by the four retained stand characteristics; basal area, stand age, time since last thinning and thinning intensity. Analysis is carried out either on the whole data set or by species. Basal area was a strong explanatory variable for all four species, with $66,51,27$, and $71 \%$ of the whole transmittance variance explained by this single variable for respectively Douglas fir, Norway spruce, larch and Scots pine. Depending on the species, the other three variables added singly or in combination to the basal area sometimes improved transmittance prediction, sometimes not. Stand age strongly affected the transmittance in larch stands, more weakly in Norway spruce and Scots pine stands, and was only slightly significant in Douglas fir stands. Thinning features were influential in Douglas fir stands, but less so for Norway spruce and larch. For the three species with thinning information, the models that took into account at least one of the thinning features had the best values of adjusted $R^{2}$.

\subsection{Qualitative derivation of the effects of stand parameters}

Figure 2 presents light transmittance values plotted against the main explanatory variable, i.e., stand basal area. For all four 


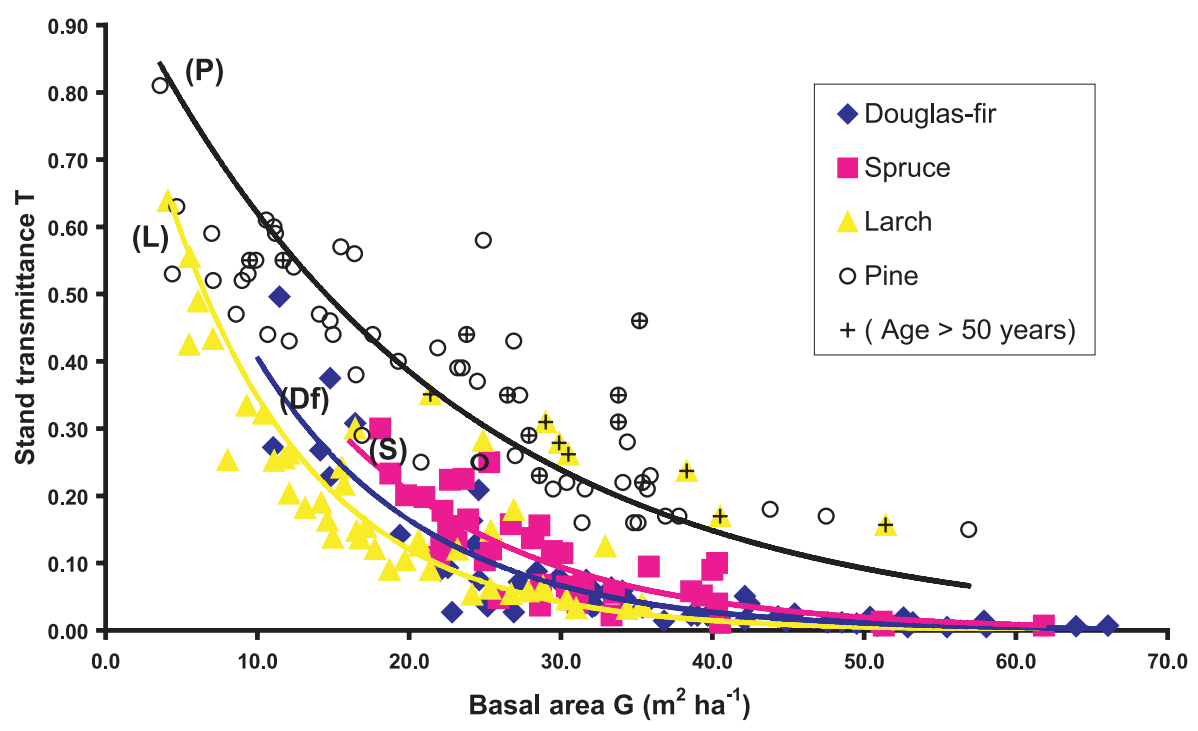

Figure 2. Stand transmittance as a function of basal area, by species. Fitting curves correspond to the one-parameter negative exponential relationship (2) and are identified by the initials of the species. Stands older than 50 years are highlighted.

species, the light transmission follows an exponential decreasing function of stand basal area, but the curve parameters are specific to each species.

For a given basal area, stand age influenced this relationship by increasing transmission in very young or very old stands (see aged plots highlighted in Fig. 2). In recently thinned stands, solar radiation transmission was in many cases greater than for unthinned stands with a similar basal area, but this difference decreased as time since thinning increased (data not shown). Thus the influences of stand age, time since last thinning and intensity of last thinning on extinction coefficient $b$ (relationship (2)) were further analyzed.

The variations of $b$ according to stand age are shown in Figure 3. The pattern of the relationship between $b$ and stand age varied among the four species: Douglas fir values were very widely spread for a moderate range of ages, and so for this species stand age influence on $b$ was not demonstrated. Norway spruce, larch and Scots pine presented a decreasing trend of $b$ with increasing stand ages. For larch, $b$ first increased with stand age and then decreased with older stands. The same trend was shown qualitatively for Norway spruce, but the increase at lower ages was not statistically significant. This type of relationship can be described by an asymmetric three-parameter function passing through the origin of the axes on the left (as canopy extinction coefficient is initially equal to zero), and tending asymptotically to zero to the right of the age axis:

$$
f(x)=a x^{p} e^{q x}
$$

where $a, p$ and $q$ are parameters. To have parameters with a practical meaning, we can rewrite relationship (3) using as parameters the coordinates of the maximum of $f(x)$, which will be called respectively $b_{\max }$ and $a g e_{\max }$, with $b_{\max }=f\left(a g e_{\max }\right)$. In this case, $a$ and $q$ can be computed as:

$$
a=b_{\max }\left(\frac{e}{a g e_{\max }}\right)^{p} \text { and } q=-\frac{p}{a g e_{\max }}
$$

and relationship (3) can be written:

$$
b(a g e)=b_{\max }\left(\frac{a g e}{a g e_{\max }} e^{\left(1-\frac{a g e}{a g e_{\max }}\right)}\right)^{p}=b_{\max } b_{a g e}
$$

where $b_{\max }, a g e_{\max }$ and $p$ are parameters, and $b(a g e)=$ $\left(\frac{a g e}{a g e_{\max }} e^{1-\frac{a g e}{a g e_{\max }}}\right)^{p}$ is an age-correcting coefficient for $b_{\text {max }}$, the maximum value of which is equal to 1 when age $=$ $a_{\text {age }} e_{\max }$ or parameter $p=0$ when no age influence exists. Dashed curves on Figure 3 represent relationship (4) with parameters $b_{\max }, a g e_{\max }$ and $p$ fitted from experimental data, by species. Mathematically, parameter $p$ drives the decreasing rate of extinction coefficient $b$ with age, on the both sides of $a g e_{\max }$ value. Actually, the shape of the relationship (4) depends on $p$ and also on the ratio p/age $e_{\max }$. Therefore possible values of these parameters are correlated (i.e small age $e_{\max }$ values impose small $p$ values in order to remain in the experimental range of extinction coefficient $b$ values).

A qualitative analysis of the influences of time since last thinning $(\tau)$ and thinning intensity $(I)$ on extinction coefficient $b$ showed that coefficient $b$ slightly increased with $\tau$ for all species, decreased with $I$ for Douglas fir, and increased with $I$ for larch. A simple function that could describe these effects is a two-parameter function, with an asymptotic shape according to $\tau$, namely:

$$
b_{\text {thinning }}=1+u \Delta_{G} e^{-v \tau}
$$

where $u$ and $v$ are parameters, and $\Delta_{G}=\frac{I}{1-I}$. This function is a thinning correction factor equal to 1 when $I=0$ or when $\tau \rightarrow \infty$. It can be larger or smaller than 1 , depending on the sign of the parameter $u$. 

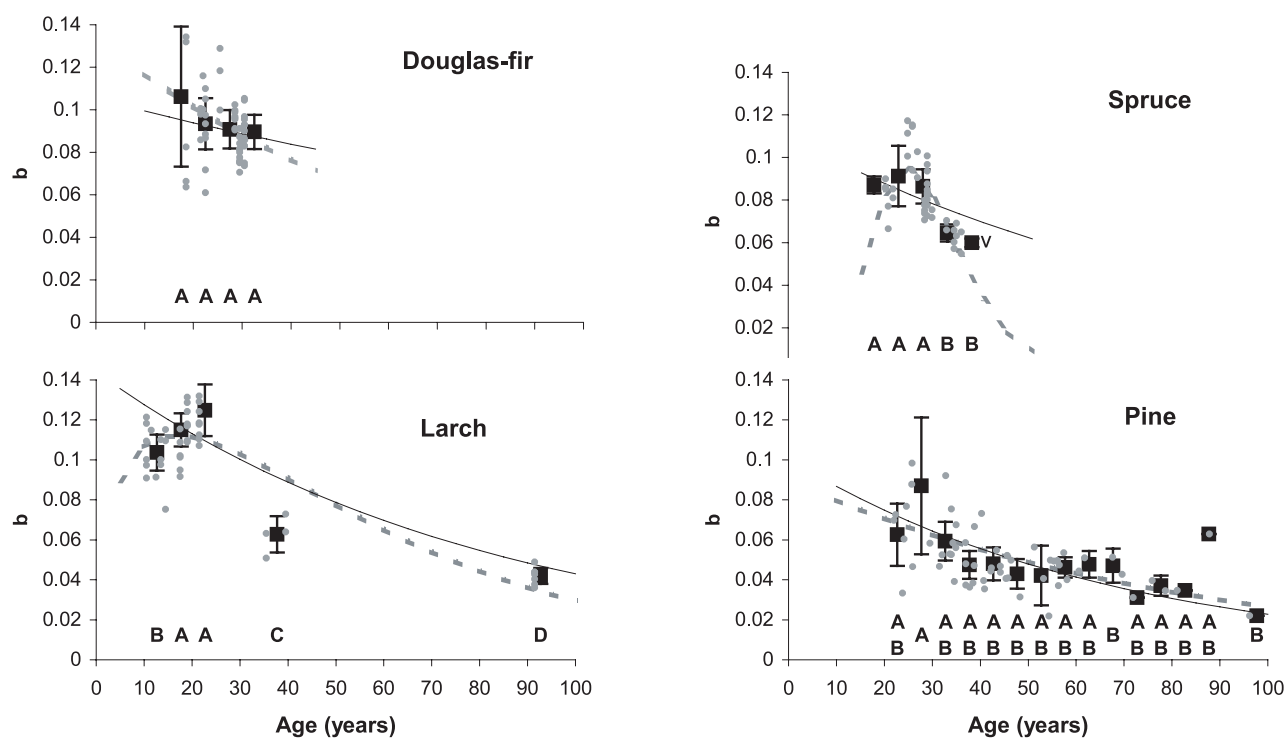

Figure 3. $G$-related extinction coefficient $b$ as a function of stand age. Points are values corresponding to individual stands. Squares are mean values by class age, and bars show standard error values. Dashed lines are fittings of the Model $2 \mathrm{~b}$ variation with age (see relationship (4)) and solid lines correspond to Model 3S age correction (relationship (6)). Letters present multiple mean comparison results (SAS/STAT, StudentNewman-Keuls method): different letters indicate statistically significant differences between means, with mean values decreasing with alphabetical order.

\subsection{Assessment of different solar radiation transmission models}

\subsubsection{Model 1: one-parameter negative exponential light extinction model}

This is the simplest model accounting for light transmission under a canopy, using the Beer-Lambert law (2) with extinction coefficient $b$ constant for a given species.

Results are presented in Table II, fitting curves on Figure 1 and plots of predicted data against measured data in Figure 5a. The values of the extinction coefficient $b$ are different between species, ranging from 0.048 for Scots pine to 0.106 for larch (Tab. II) so larch presented the lowest stand transmittance and Scots pine the highest at the same basal area values (Fig. 2).

This simple model presented adjusted $R$-square values between 0.56 (for Norway spruce) and 0.80 (for Douglas fir), so explaining much of the irradiance variation in forest stands.

\subsubsection{Model 2: age-corrected negative exponential light extinction model}

Instead of taking coefficient $b$ as constant, this model expresses the extinction coefficient $b$ as a function of stand age, using relationship (3). Results are presented in Table II and Figure $5 b$. The fitting of this model was impossible for Douglas fir as there was no obvious stand age influence on $b$ values, as shown before. Moreover, the $R$-square value decreased for Douglas fir when applying this model. On the contrary, for Norway spruce, larch and Scots pine the age-corrected model significantly enhanced $R$-square values (Tab. II). As shown in
Figure 3, the curves for $b$ according to stand age can present a peak at around 20 years (Norway spruce and larch) or decrease monotonically (when $a g e_{\max }$ fitted values are close to 0 , as for Douglas and Scots pine). The values of the parameter $p$ are very different between species, and model 2 is very sensitive to these values, as it will be shown below.

\subsubsection{Model 3: thinning- and age-corrected negative exponential light extinction model}

As shown above, thinning characteristics had a weak influence on light regime, and to test the significance of this effect, transmittance was also expressed as a function of time since last thinning and the intensity of this thinning:

$$
T=e^{-b_{\max } b_{a g e} b_{\text {thinning }} G}
$$

with $b_{\text {thinning }}=1+u \Delta_{G} e^{-v \tau}(5)$, parameters $b_{\max }$, age $e_{\max }$, $p, u$ and $v$ being fitted from data. Scots pine stands were not included in this model assessment as no data was available on thinning for this species. Results are presented in Table II and Figure $4 \mathrm{c}$. Parameters $b_{\max }, a g e_{\max }$ and $p$ are considerably modified by this new fitting compared with model 2 for Douglas fir and larch, while Norway spruce parameter values remain stable. The $u$ values are negative and $v$-values are positive for Douglas fir and Norway spruce, which means that thinned stands have higher transmittance than unthinned ones at equal basal area values. Larch presents the opposite behavior, but the $u$ value is very small, with a large standard error value, and the $R$-square value is not enhanced by adding a thinning correction in comparison with the age-corrected only model. This means that thinning did not influence the $b$ coefficient in larch. 
Table II. Estimated values of the parameters of the proposed models, and corresponding adjusted $R$-square values, by species and for pooled data. Standard errors and estimated mean standard error respectively are given in brackets. DOU $=$ Douglas fir, SPR $=$ Norway spruce, LAR $=$ larch, PIN = Pine.

\begin{tabular}{|c|c|c|c|c|c|c|c|c|c|}
\hline \multirow{2}{*}{ Model } & \multicolumn{4}{|c|}{$\begin{array}{c}\text { Parameters values } \\
\text { (standard errors in brackets) }\end{array}$} & \multicolumn{5}{|c|}{$\begin{array}{c}\text { Adjusted } R \text { - square } \\
\text { (and estimate's standard error) }\end{array}$} \\
\hline & DOU & SPR & LAR & PIN & $\begin{array}{c}\text { DOU } \\
n=54\end{array}$ & $\begin{array}{c}\text { SPR } \\
n=41\end{array}$ & $\begin{array}{c}\text { LAR } \\
n=49\end{array}$ & $\begin{array}{c}\text { PIN } \\
n=60\end{array}$ & $\begin{array}{l}\text { All data } \\
n=204\end{array}$ \\
\hline \multicolumn{10}{|l|}{ Model 1} \\
\hline$T=e^{-b G}$ & $\begin{array}{c}b=0.0903 \\
(0.0027)\end{array}$ & $\begin{array}{c}b=0.0788 \\
(0.0021)\end{array}$ & $\begin{array}{c}b=0.1056 \\
(0.0059)\end{array}$ & $\begin{array}{c}b=0.0477 \\
(0.0020)\end{array}$ & $\begin{array}{c}0.804 \\
(0.039)\end{array}$ & $\begin{array}{c}0.556 \\
(0.039)\end{array}$ & $\begin{array}{c}0.623 \\
(0.099)\end{array}$ & $\begin{array}{l}0.731 \\
(0.104)\end{array}$ & $\begin{array}{c}0.824 \\
(0.080)\end{array}$ \\
\hline \multicolumn{10}{|l|}{ Model 2} \\
\hline $\begin{array}{l}\quad T=e^{-b_{\max } b_{\text {age }} G} \\
\text { with } b_{\text {age }}=\left(\frac{a g e}{a g e_{\max }} e^{1 \frac{a g e}{a g e_{\max }}}\right) \\
\text { (dashed lines on Fig. 3) }\end{array}$ & $\begin{array}{c}b_{\max }=0.1324 \\
(0.8753) \\
a g e_{\max }=0.241 \\
\text { (years) } \\
(3.65) \\
p=0.0034 \\
(0.1592)\end{array}$ & $\begin{array}{c}b_{\max }=0.0948 \\
(0.0026) \\
a g e_{\max }=24.40 \\
\text { (years) } \\
\quad(0.56) \\
p=7.152 \\
(1.459)\end{array}$ & $\begin{array}{c}b_{\max }=0.1179 \\
(0.0033) \\
\text { age }_{\max }=18.13 \\
\text { (years) } \\
(1.05) \\
p=1.533 \\
(0.361)\end{array}$ & $\begin{array}{l}b_{\max }=0.0904 \\
\quad(0.0116) \\
\text { age } e_{\max }=0.04 \\
\text { (years) } \\
\quad(.) \\
p=0.0005 \\
(0.0001)\end{array}$ & $\begin{array}{c}0.786 \\
(0.037)\end{array}$ & $\begin{array}{c}0.834 \\
(0.027)\end{array}$ & $\begin{array}{c}0.867 \\
(0.057)\end{array}$ & $\begin{array}{c}0.776 \\
(0.089)\end{array}$ & $\begin{array}{c}0.886 \\
(0.061)\end{array}$ \\
\hline \multicolumn{10}{|l|}{ Model 3} \\
\hline with $T=e^{-b_{\max }^{\prime} b_{\text {age }}^{\prime} b_{\text {thinning }} G}$ & $b^{\prime} \max _{(0.0268)}=0.1922$ & $b^{\prime} \max _{(0.0030)}=0.0987$ & $b^{\prime} \max _{(0.0034)}=0.1076$ & - & $\begin{array}{c}0.865 \\
(0.036)\end{array}$ & $\begin{array}{c}0.875 \\
(0.026)\end{array}$ & $\begin{array}{c}0.865 \\
(0.051)\end{array}$ & - & $\begin{array}{c}0.894 \\
(0.039)\end{array}$ \\
\hline $\begin{array}{l}b_{\text {age }}^{\prime}=\left(\frac{a g e}{a g e_{\max }^{\prime}} e^{1 \frac{a g e}{a g e_{\max }^{\prime}}}\right) \\
b_{\text {thinning }}=1+u \Delta_{G} e^{-v \tau}\end{array}$ & $\begin{array}{c}a g e^{\prime} \max _{(\mathrm{years})}=0.233 \\
(.) \\
p^{\prime}=0.0062 \\
(0.0012 \\
u=-0.310 \\
(0.067) \\
v=0.293 \\
(0.169)\end{array}$ & $\begin{array}{c}3 \text { age }^{\prime} \max _{(\text {years }}=24.35 \\
(0.556) \\
p^{\prime}=6.99 \\
(1.38) \\
u=-0.236 \\
(0.151) \\
v=0.752 \\
(1.022)\end{array}$ & $\begin{array}{c}\text { age }_{\text {max }}^{\prime}=12.91 \\
(\text { years }) \\
(4.11) \\
p^{\prime}=0.3215 \\
(0.173) \\
u=0.048 \\
(0.043) \\
v=-0.22 \\
(0.134)\end{array}$ & - & & & & & \\
\hline
\end{tabular}

$$
\text { age* }=20 \text { years, } b^{*}=\bar{b}_{(10<\text { age }<30)}
$$

\begin{tabular}{|c|c|c|c|c|c|c|c|c|c|}
\hline$T=e^{-b^{*} b_{\text {age }}^{*} b_{\text {thinning }}^{*} G}$ & $b^{*}=0.0939$ & $b^{*}=0.0876$ & $b^{*}=0.1131$ & $b^{*}=0.0748$ & 0.857 & 0.728 & 0.866 & 0.765 & 0.880 \\
\hline$b^{*}=\bar{b}\left(\right.$ age $\left.e^{*}\right)$ & $(0.0031)$ & $(0.0024)$ & $(0.0028)$ & $(0.0097)$ & $(0.041)$ & $(0.040)$ & $(0.058)$ & $(0.091)$ & $(0.063)$ \\
\hline (fitted from measurement data) & $z=0.00568$ & $z=0.01161$ & $z=0.0121$ & $z=0.0148$ & & & & & \\
\hline$b_{\text {age }}^{*}=e^{-\tau\left(\text { age }-a g e^{*}\right)}$ & $(0.0035)$ & $(0.0033)$ & $(0.0020)$ & $(0.0018)$ & & & & & \\
\hline
\end{tabular}

$b_{\text {thinning }}^{*}=1-0.3 \Delta_{G} e^{-0.5 \tau}$
$\left(b_{\text {thinning }}^{*}=1\right.$ for missing thinning data $)$

[For comparison, $b *$ values calculated with model 3 (model 2 for Pine) at age* $=20$ years:

$\begin{array}{llll}0.1014 & 0.08303 & 0.1115 & 0.0711]\end{array}$

\subsubsection{Alternative models and/or sets of data}

As Douglas fir was only slightly sensitive to stand age and more sensitive to thinning variables, a simple thinning corrected model was applied to Douglas fir data $T=e^{-b_{\max } b_{\text {thinning }} G}$. This model gave an adjusted $R^{2}$ of 0.863 and the following parameter values: $b_{\max }=0.0956, u=-0.178, v=0.348$ (compare with those in Tab. II, model 3). This shows that the best $R$-square values can be reached by applying only a thinning correction to Douglas fir stand data. For Norway spruce, this alternative model raised $R^{2}$ values from 0.556 (model 1) to 0.662 , and parameter values were close to those of model $3\left(b_{\max }=0.0857, u=-0.235\right.$, $v=0.746$ ). For larch, differences were greater (data not shown), but larch data did not show significant sensitivity to thinning, as seen before. 
(a)

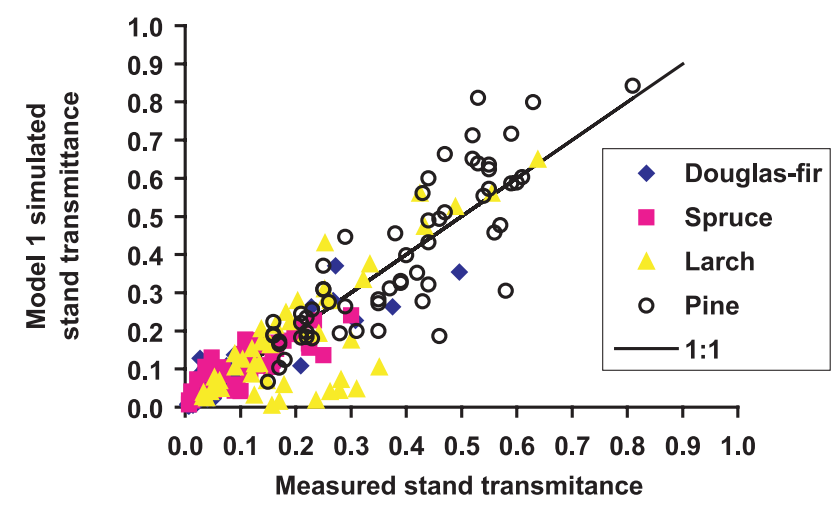

(b)

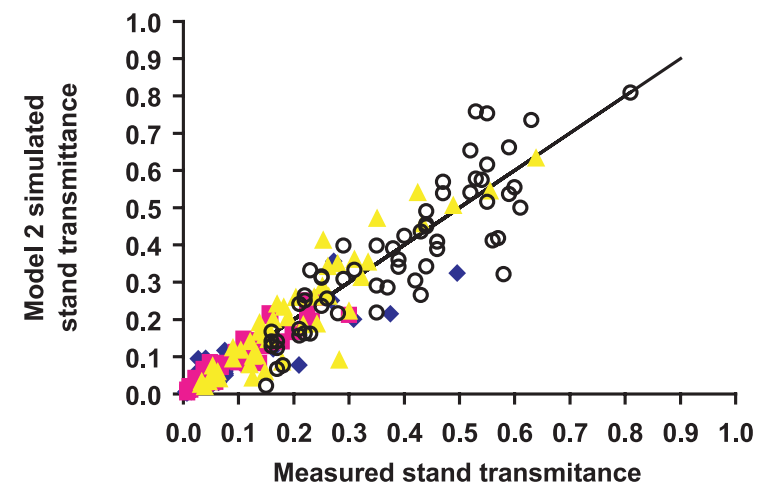

(c)

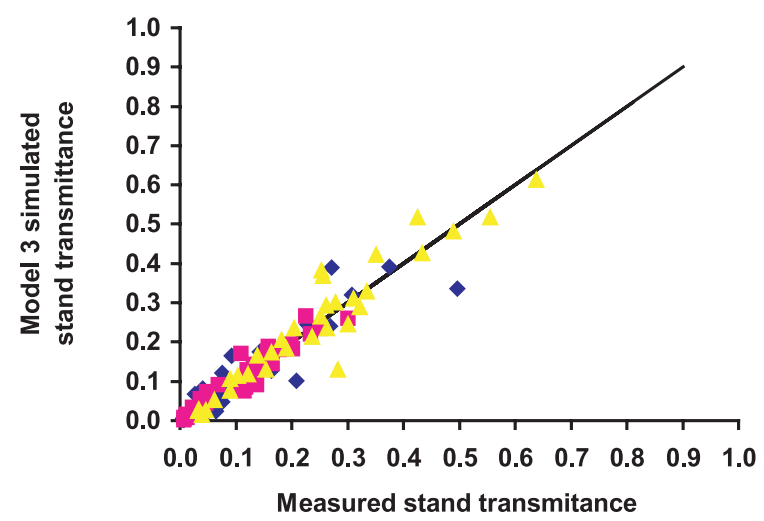

Figure 4. Comparison between measured and simulated transmittance values for the different models, for data pooled along species. (4a) for model $1,(4 \mathrm{~b})$ for model 2 and $(4 \mathrm{c})$ for model $3 \mathrm{~S}$ fitted on only data concerning stands with available thinning information.

Model 3 was tested against all the experimental data (Tab. II, last column) by considering $b_{\text {thinning }}=1$ for stands with unavailable thinning data. Unknown possible thinning effects were thus included in coefficient $b$ variability. Considering only data where thinning information was available, the number of obser- vations decreases to $n=42, n=26$ and $n=21$ for Douglas fir, Norway spruce and larch respectively (against $n=54, n=41$ and $n=49$ respectively considering all data). Corresponding adjusted $R^{2}$ values are, in this case, 0.724 for model 1 (constant $b$ values), 0.873 for model 2 (age-corrected values), and 0.918 for model 3 (age and thinning corrected values), which confirms model 3 better fitting.

Finally, as stand ages were mainly below 50 years (only $13 \%$ of values were above, mainly from the Scots pine data), models 1 , 2 and 3 were fitted and afterwards compared to data corresponding only to age $<50$ years. Pooling all species, adjusted $R^{2}$ values were respectively $0.883,0.909$, and 0.914 for models 1 , 2 and 3, all greater than those of models fitted with all stand age data (see Tab. II).

\subsection{Sensitivity analysis}

Transmittance sensitivity to parameters $b_{\max }, a g e_{\max }$ and $p$ are presented in Figures 5a, $5 \mathrm{~b}$ and $5 \mathrm{c}$ respectively. The figures present isolines for $\mathrm{d} T / T$ values computed from model 2 and model 3, as a function of stand age and basal area. Values of $\mathrm{d} T / T$ up to 0.5 are presented, as transmittance $T$ rapidly decreases with stand basal area (50\% of total data amount had $T$ values less than 15\%) and measurement precision is of a few percent order. Typical parameters values were chosen as follows: ag $e_{\max }=20$ years, $b_{\max }=0.1, p=1$. Figures backround is representing measured values set, in order to account on real basal area - age values range.

Figure 5a shows that models 2 and 3 sensitivity against $b_{\max }$ values is maximal for age $=a g e_{\max }$ at the same basal area. It increases with increasing basal area, but with a lower rate for advanced ages. For model 1, which does not present age dependence, corresponding sensitivity values are those corresponding to age $_{\max }$ value on the abscissa. Figure $5 \mathrm{~b}$ shows model sensitivity to $a g e_{\max }$, variation, which is greatest around $2 a g e_{\max }$, i.e., 40 years for our parameter value set. We can conclude that models are generally quite stable against variations in both parameters $b_{\max }$ and $a g e_{\max }$, except for particular age values $\left(\right.$ age $_{\max }, 2$ age $\left._{\max }\right)$ and for basal area values above $50 \mathrm{~m}^{2} \mathrm{ha}^{-1}$.

Sensitivity analysis for parameter $p$ (Fig. 5c) was carried out for an absolute variation of one unit for $p$, at $p=1$. Except for ages around $a g e_{\max }$, models 2 and 3 show a high sensitivity to parameter $p$, a variation of $50 \%$ for transmittance $T$ being already reached at basal area values of around $20 \mathrm{~m}^{2} \mathrm{ha}^{-1}$. Also, relative variation of transmittance $T$ increases linearly with $p$. Since $p$ values range widely among species (from 0 for pine to 7 for spruce), and also standard errors of estimated $p$ values are high, the models are unstable against the $p$ parameter.

Concerning $u$ and $v, \mathrm{~d} T / T$ values always remain less than 0.4 for all considered age and basal area values, and so model 3 is robust enough for these parameters (some type of figures, not shown).

\subsection{Model 3S: a simplified model}

\subsubsection{Model 3S derivation}

Model 3 presented above, which takes stand age and thinning characteristics into account, yields satisfactory values of adjusted $R^{2}$. However, estimating five parameters can induce 
a)

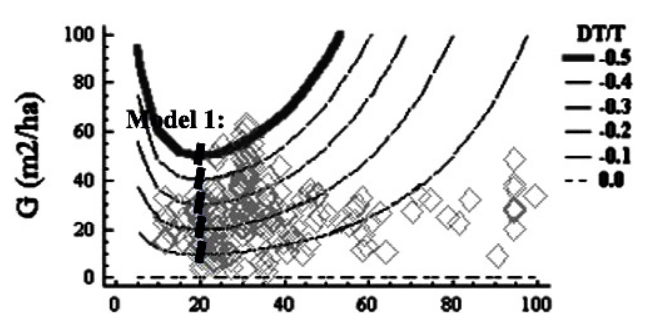

b)

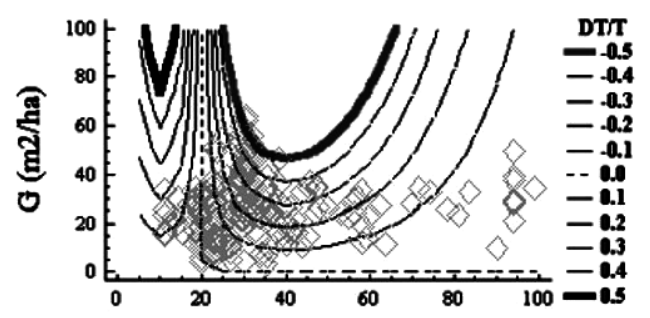

c)

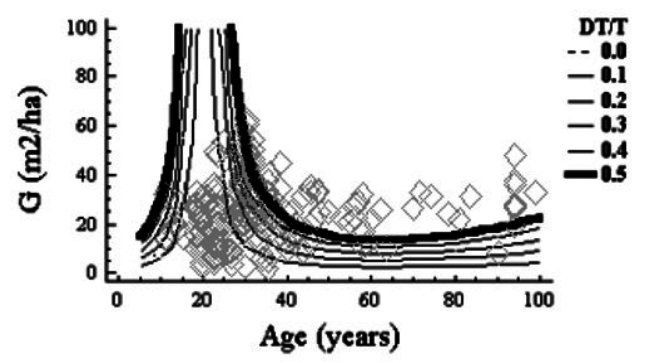

Figure 5. Sensitivity analysis of models 2 and 3 , for parameters $b_{\max }$, $a_{g e} e_{\max }$, and $p$. Figures show relative variation of transmittance $\mathrm{d} T / T$ for a relative variation of 0.1 for $b_{\max }$ (Fig. 5a), and $a g e_{\max }$ (Fig. 5b), and for an absolute variation of one unit for parameter $p$ (Fig. 5c), at typical parameter values of $b_{\max }=0.1$, age $e_{\max }=20$ years, and $p=1$. Lines are isolines of $\mathrm{d} T / T$ values, as a function of basal area $(G)$ and stand age. Legend identifies $0.0,0.5$ and -0.5 isolines, and between these values $\mathrm{d} T / T$ variation is monotonic. Grey diamonds in the background are the experimental points. Figure 5a presents also the sensitivity analysis of model 1 for $b_{\max }$ parameter, i.e. at age equals 20 years (the typical $a g e_{\max }$ value chosen for this analysis).

marked instability in some cases and NLIN procedure convergence could be local in these cases (i.e., strongly dependent on the values used to initialize the parameters). Thus a simplified model with fewer parameters would be useful. It will be derived from some general traits deduced from the previously presented models.

Concerning the influence of stand age, the general trend is a fall in $b$ values, beginning at some particular age. Assuming that the decrease in $b$ begins with an age value $a g e^{*}$, then $b$ decreases asymptotically, and the simplest law for the correction coefficient is in this case a negative exponential function:

$$
b_{\text {age }}^{*}=e^{-z\left(\operatorname{age}-a g e^{*}\right)}
$$

where $z$ is a parameter to be fitted from the data.
Table III. Analysis of model 3S robustness and predictivity from randomly sampled subsets of data, by species: means of parameter $z$ (relationship (6)) fitted values, variation coefficients of those values, and mean standard errors of the model on test data subsets.

\begin{tabular}{lcccc}
\hline & Douglas-fir & Spruce & Larch & Pine \\
\hline $\bar{Z}$ & 0.00595 & 0.01108 & 0.01183 & 0.01523 \\
Variation & $20.94 \%$ & $14.64 \%$ & $7.66 \%$ & $5.27 \%$ \\
coefficient $\mathrm{CVr}$ & & & & \\
$M S E_{\text {test }}$ & $4.91 \%$ & $1.48 \%$ & $4.19 \%$ & $1.83 \%$ \\
\hline
\end{tabular}

The thinning correction can be considered the same for all species, deduced from the experimental data for the species that showed the highest sensitivity to thinning characteristics, namely Douglas fir and Norway spruce. Approximate means of $u$ and $v$ values could be considered respectively $u=-0.3$, and $v=0.5$, so the thinning correction could have the expression:

$$
b_{\text {thinning }}^{*}=1-0.3 \Delta_{G} e^{-0.5 \tau} \text {. }
$$

Therefore, from equations (6) and (7), a simplified relationship for light transmittance could be written:

$$
T=e^{-b^{*} b_{a g e}^{*} b_{\text {thining }}^{*} G} \text {. }
$$

The value of $b^{*}$, can be directly deduced from experimental data, as the mean of the measured extinction coefficient $b$ corresponding to an age class including age*. For example, in this study, age $e^{*}=20$ years, and $b^{*}=\bar{b}_{(10<a g e<30)}$. In this case, $z$ remains the single parameter to be fitted with a NLIN procedure applied on experimental data.

\subsubsection{Model 3S assesment}

Results of applying model $3 \mathrm{~S}$ are presented in Table II and Figure $4 \mathrm{c}$. The model was applied on all data, and for the stand with missing information on thinning $b^{*}$ thinning was considered equal to 1 . Adjusted $R^{2}$ values for model $3 \mathrm{~S}$ were only slightly below the best $R^{2}$ values obtained with models 2 or 3 for Douglas fir, Norway spruce and Scots pine, and the same for larch, but were better than values obtained with model 1 .

The sensitivity of model $3 \mathrm{~S}$ to parameter $z$ was assessed using the same procedure as described above. Values of $\mathrm{d} T / T$ are all less than 0.4 for all age and basal area values, so model $3 \mathrm{~S}$ can be considered stable enough against parameter $z$ (data not shown).

\subsubsection{Model 3S simulation and validation}

Figure 6 presents some simulations of model 3S for age $e^{*}=$ 20 years and two thinning situations (no thinning and thinning three years previously at intensity $I=0.5)$, and two $b^{*}$ values (0.11 and 0.08). For a given basal area, thinning induces an increase of transmittance values. Transmittance increases also with age, and with a lower extinction coefficient $b^{*}$. Differences between transmittance values can be very marked for basal area values greater than $10 \mathrm{~m}^{2} \mathrm{ha}^{-1}$. For example, $T$ varies from $5 \%$ to more than $40 \%$ between stands aged 20 years and 80 years at a $20 \mathrm{~m}^{2} \mathrm{ha}^{-1}$ basal area. Table III presents averages and variation coefficients $\mathrm{CV}$ for $z$ values obtained from randomly sampled subsets of data (as presented in Materials and 


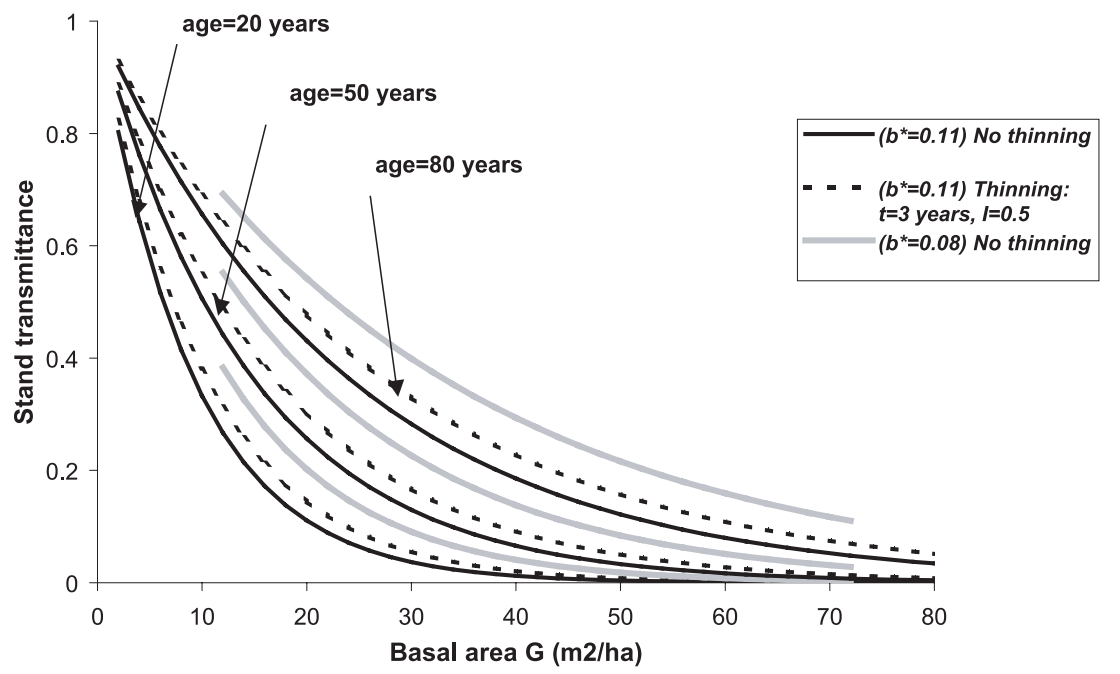

Figure 6. Simulated stand transmittance as a function of basal area, obtained with model $3 \mathrm{~S}$ for three stand ages $(20,50$, and 80 years, as indicated on the figure). Black lines: $b^{*}=0.11$. Grey lines: $b^{*}=0.08$. Solid lines: unthinned stands. Dashed lines: thinning of intensity $=0.5,3$ years ago. Parameter age $\max$ was set at 20 years.

methods), together with mean standard error averages for test subsets. CV of $z$ values fitted on data subsets ranged from $5 \%$ to $21 \%$, with the highest values for Douglas fir stands. The mean standard error of the model applied on test subsets had averaged values between $2 \%$ and $5 \%$.

\section{DISCUSSION}

This study reports the results of global solar radiation measurements under forest stands of four coniferous species (Douglas fir, Norway spruce, larch and Scots pine) and different models to predict light availability in their understory from easily measurable tree or stand characteristics. The data sets analyzed were large, with a total of 204 measurement plots, among which 89 had complete thinning information. This total plot number was relatively well balanced among the four species. Different soil and climate conditions were sampled and data covered stand ages from 10 to 96 years and stand basal area values from 11 to $66 \mathrm{~m}^{2} \mathrm{ha}^{-1}$, for which solar radiation transmittance ranged between 4 and $81 \%$. The data set was therefore representative of a large range of coniferous stands for the four species considered and conditions in the temperate zone. We found no effect of site richness (soil and climate) on the relationships between mean relative irradiance and stand basal area. Therefore, the relationships seem rather insensitive to this factor. This could be expected because the relationship between the basal area and the leaf area, which determines the light transmission, is also rather stable.

Concerning tube solarimeters use for measurements, Sattin et al. [54] showed that the standard error of average transmittance stabilizes with 2 to 3 tube solarimeters for a fairly homogeneous canopy with normally distributed transmittance values. For more heterogeneous covers, with a variation coefficient greater than $20 \%$, a higher number of tube solarimeters (5 to 6 ) is needed $[6,51]$. Tube solarimeter geometry allows the integration of radiation spatial variability over their length of about
$1 \mathrm{~m}$ and so they give better results than point sensors in predicting mean transmittance in heterogeneous cover [54], but they can also be a source of measurement error, depending on their orientation according to sun course and canopy spatial layout (e.g. [41] for tropical behavior).

As canopy optical properties are different for different wavebands, canopy transmittance values also vary according to the waveband considered; hence caution is necessary when comparing results and/or converting between the different waveband ranges. Some relationships are available to convert global radiation into PAR and vice-versa, but although conversion rate between overstory global radiations and PAR is quite constant, depending slightly on cloud cover [13, 63], understory transmittance of PAR radiation is lower than global solar radiation transmittance and the difference depends on canopy closure and leaf optical properties induced by species, clone, seasonal development, environmental factors, etc. ([21, 54] for Turkey oak, [12] for Douglas fir, [29] for Sitka spruce). Therefore, this type of relationship, though not invalid, must be used with caution.

As in previous works, we found a negative exponential relationship between light transmittance and stand basal area, which explained between $56 \%$ and $80 \%$ of transmittance variation according to the species, and $82 \%$ for all species pooled data. For a stand age around 73 years, Kuusipalo [33] found that basal area explained $75 \%$ of light transmittance in Norway spruce and Scots pine for a basal area ranging from 14 to $37 \mathrm{~m}^{2} \mathrm{ha}^{-1}$. Comeau [19] reported a logarithmic relationship that explained $88 \%$ of light transmittance variation in young aspen (Populus tremuloides Michx.), for basal area between 5 and $40 \mathrm{~m}^{2} \mathrm{ha}^{-1}$. Hale [29] found a similar relationship for ponderosa pine (Pinus ponderosa Dougl.) stands. As pointed out by Hale [29], in some of these studies, for values of basal area above a specific threshold (from $15 \mathrm{~m}^{2} \mathrm{ha}^{-1}$ to $30 \mathrm{~m}^{2} \mathrm{ha}^{-1}$ ) light transmittance values became very low and independent of basal area. Ferment et al. [23] found in a tropical forest few significant correlations between light measures and trees basal area 
within $10 \mathrm{~m}$, possible due to the light extinction induced by below $10 \mathrm{~cm} D B H$ stems. For our measurements, the 10 experimental points with the lowest transmittance values for each species still showed a good negative correlation (with $R$-square values ranging from 0.38 to 0.76 ) between transmittance and stand basal area values.

The relationship have an exponential form, following the Beer-Lambert formalism for light extinction (see Eq. (1)). In our case we measured transmittance at ground level, i.e. as influenced by the whole tree $L A I$. We did not measure $L A I$ in this study because it is not a variable that is easily accessible for forest managers. However, a close relationship between the basal area of a tree and its leaf area has been frequently reported and used in the "pipe" models [55, 65, 66]. Therefore, it is not surprising that the variable that accounts for most of the relative irradiance variability is the basal area.

Other variables added to the basal area can improve the prediction of transmittance, such as tree height, crown height, crown length/total tree height, height of the first green whorl, etc. but never to an extent (only a few percent of the variability) that justifies adding them to the relationships [51]. Exceptions are stand age and stand thinning characteristics, which enhanced the basic negative exponential model for solar radiation transmittance, with different behaviors for the four species considered. For Douglas fir and Norway spruce the model was markedly improved by applying both age and thinning correction, while data concerning larch were not sensitive to thinning correction.

The variations of the $G$-extinction coefficient $b$ is actually a combined effect of the variation of $L A I$-extinction coefficient $k$ from the Beer-Lambert law and the variation of the slope $a$ between $L A I$ and basal area $G$ (see relationship (2)). Diverse studies have dealt with the influence of stand characteristics on one or another of these coefficients. Sampson and Smith [52] showed for lodgepole pine (Pinus contorta var. latifolia) that canopy light extinction coefficient $k$ depends on solar elevation, canopy LAI, foliage aggregation, average leaf inclination angle and vertical foliage distribution. They found a negative correlation between $k$ and cover LAI. Our data also presented a negative correlation between extinction coefficient $b$ and basal area $G$, except for Norway spruce, but this dependency diminished for age-corrected coefficient $b$ (data not shown). Lower extinction coefficient $b$ values for pine may indicate clumping in its foliage. For similar foliage aggregation, differences in $b$ values could be an indicator of different mean leaf inclination angle. Black et al. [12] found strong planophile characteristics for Douglas fir stands. This trend could be coherent with the higher $b$ values for Douglas-fir found with our data.

Concerning age influence on extinction coefficients, Turner et al. [61] reported that estimated LAI from basal area measurements was higher than those based on sapwood area in older Douglas fir stands, which could signify that slope $a$ linking basal area to actual $L A I$ decreased for old stands. Brown and Parker [14] reported for mixed species deciduous forests that $k$ was lowest for youngest stands, increased toward age 50 years and declined with age in the oldest sites (65-340 years). Porté et al. [47] reported the slope $a$ of the relationship between crown foliage area and basal area in maritime pine (Pinus pinaster Ait.) decreased with stand age. Usolstev and Hoffmann [62] showed that for Norway spruce, foliage biomass varied with stand age, with a maximum between 40 and 60 years, while branch biomass presented an inverse behavior, reaching a minimum value at an age about of 50 years. Considering branch biomass as an expression of trunk size, this leads to an initial increase of slope $a$ at low ages followed by a decrease with advanced ages. The above proposed relationship (3) between extinction coefficient $b$ and stand age can describe not only the decrease of extinction coefficient at advanced age, but also a possible increase at low ages to a maximum value. This function presented the best agreement with experimental data (models 2 and 3), but was very sensitive to the parameter $p$, and so its predictive use is limited to a sufficient data set to calibrate the model. For example, fitting function (3) was critical in the case of Douglas fir where data presented few stand age classes. A simpler function is an asymptotic decrease of the extinction coefficient with age increase (6). However, its use may be inaccurate for young ages for species whose extinction coefficient decreases in their young age.

Correction for extinction coefficient $b$ due to thinning characteristics (stem sampling intensity and time since last thinning) was important for Douglas fir and Norway spruce. Proposed relationship (5) can equally describe values higher or less than 1 (depending on the sign of parameter $u$ ), and tends to 1 as the time since last thinning increases. Under the turbid medium approach for light transmission, this correction can be related to the clumping coefficient often used to multiply the extinction coefficient in the Beer-Lambert law to account for foliage clumping [42]. When $u$ is negative, the thinning correction (5) is less than 1 , which means that transmittance is higher, which can be explained by a more clumped foliage after thinning than in unthinned stands. This is realistic as thinned stands present a heterogeneous canopy with a larger number of gaps immediately after thinning. A negative value of parameter $u$ can be obtained particularly when thinning is performed too late, with a high value of $G$, which means that tree crowns are limited in their extension. Consequently, extinction coefficient $b$ decreases with stand basal area $G$ in unthinned stands and so thinned stands will initially have the lower $b$ value corresponding to higher basal area before thinning. Conversely, a positive value of $u$ would mean, by analogy with the clumping parameter, that the canopy becomes more regular after thinning. Again this would be possible, for example, when thinning acts to improve canopy regularity, and/or trees have a good plasticity and a structure that changes quickly after thinning. This is the case for larch, a light-demanding species, and its slightly positive $u$ parameter value fitted with model 3 may account for these properties. Similar results have been reported for various species. For instance, Hale [29] showed that thinning induces a decrease in extinction coefficient $k$ in ponderosa pine (Pinus ponderosa Dougl.). Granier [26] found for Douglas fir that the slope between foliage mass and sapwood basal area did not depend on age or stocking for unthinned stands, but increased after stand thinning.

Previous works had also demonstrated the influence of vertical foliage distribution on the canopy extinction coefficient [14, 52]. Medhurst and Beadle [36] reported for Eucalyptus nitens that thinning did not affect the relationship between branch size and branch area, or branch inclination angles, but vertical leaf distribution of thinned trees was less skewed 
toward the crown top than in unthinned stands, which could bring about an increase in canopy extinction coefficient $k$. Among the stand characteristics that are easiest to measure, total stem and crown heights could lead to a synthetic variable that could account for vertical leaf distribution. In this study these variables had insufficient weight in the general linear model analysis for stand transmittance to be maintained, so they were not used in the models proposed above. Nevertheless, it would be interesting to further analyze their effects on the extinction coefficient $b$, corrected for age and thinning characteristics in order to separate the effects of the different variables. A priori, stand height effects on light transmission should interfere mainly with age effects, as thinning is reported not to influence height growth (e.g., Roberts and Long [48], for Abies lasiocarpa).

\section{CONCLUSION}

This study shows that with a very simple model, needing only the measurement of stand basal area, forest managers or scientists can accurately predict mean global solar radiation transmittance in the understory of even-aged coniferous stands of Douglas fir, Norway spruce, larch and Scots pine in the temperate climate zone. For a better prediction, stand age, and also thinning intensity and time since last thinning can be added to the model. Thus the model explicitly allows to take into account managing features, which are controlled by the forester However, for use in new conditions not explored by this study, this full model needs a large set of data to adjust the different parameters.

The simplified model $3 \mathrm{~S}$ is easier to adjust, and is more convenient for predictive use. Nevertheless, the assumption that parameters $u$ and $v$ for thinning correction are general may be critical. It is expected that changes in cover structure after thinning depend on species traits such as mechanical and morphological plasticity, for example. Further analysis of data sets of larger size will be necessary to refine this point for thinned stands. However, the model can still be used by forest managers to adapt their silvicultural practice to different objectives according to light requirement, such as tree regeneration, plant biodiversity, biomass production, etc. [5]. The radiation transmittance model can also be included in more general models of silviculture, to help adapt silvicultural operations such as thinning to meet different objectives such as wood production, wood quality and biodiversity maintenance [46]. Finally, the model is obviously built with data on coniferous even-aged stands that are relatively regular and homogeneous. Its application to very heterogeneous stands (for instance with very large gaps or harvesting pathways), uneven-aged stands, or mixed stands with broad-leaved species is inadvisable until further work has been done.

Acknowledgements: The authors thank R. Jouvie, A. Marquier and F. Landré for their technical contributions in the field. They also thank D. Pauwels for her help in Belgium. The study was supported by grants from the Auvergne Region, the Auvergne Regional Directorate of Agriculture and Forest (DRAF Auvergne) and the European Community (FEOGA 5b and FAIR5 - CT 98-3354).

\section{REFERENCES}

[1] Aussenac G., La maîtrise du microclimat en plantation, Rev. For Fr. 38 (1986) 285-292.
[2] Aussenac G., Granier A., Naud R., Éclaircie systématique dans un jeune peuplement de Douglas : modifications microclimatiques et influences sur la croissance, Rev. For. Fr. 36 (1984) 279-288.

[3] Bailly A., Éclaircir les peuplements résineux : un impératif écologique, AFOCEL-ARMEF, Informations-Forêt 4 (1992) 342-348.

[4] Balandier P., Landré F., Lampin N., Ruchaud F., Understorey vegetation diversity, composition and cover according to light level under canopies of larch stands thinned with different intensities, in: "Popular summaries of the Fourth International Conference on Forest Vegetation Management”, Frochot H., Collet C., Balandier P., Compilation, Nancy, France, 17-21 June 2002, INRA, 2002, pp. 157-159.

[5] Balandier P., Pauwels D., La lumière, outil sylvicole pour favoriser la diversité végétale ou la gestion cynégétique des peuplements de mélèze (Larix sp.), Forêt Wallone 61 (2002) 9-13.

[6] Balandier P., Ruchaud F., Pauwels D., Jouvie R., Predicting light transmission through canopies of larch stands (Larix sp.) in France and Belgium, in: Pâques L.E. (Ed.), "Improvement of larch (Larix sp.) for better growth, stem form and wood quality", 2002/09/1621, Gap, Auvergne and Limousin, (FRA), INRA-Cemagref, 2002 pp. 340-349

[7] Baldocchi D., Collineau S., The physical nature of solar radiation in heterogeneous canopies: spatial and temporal attributes, in: Caldwell M.M., Pearcy R.W. (Eds.), Exploitation of Environmental heterogeneity by plants, Academic Press, 1994, pp. 21-72.

[8] Ballaré C.L., Light gaps: sensing the light opportunities in highly dynamic canopy environments, in: Caldwell M.M., Pearcy R.W. (Eds.), Exploitation of Environmental heterogeneity by plants, Academic Press, 1994, pp. 73-110.

[9] Beaudet M., Messier C., Growth and morphological responses of yellow birch, sugar maple, and beech seedlings growing under a natural light gradient, Can. J. For. Res. 28 (1998) 1007-1015.

[10] Beaudet M., Messier C., Paré D., Brisson J., Bergeron Y., Possible mechanism of sugar maple regeneration failure and replacement by beech in the Boisé-des-Muir old-growth forest, Quebec, Ecoscience 6 (1999) 264-271.

[11] Bigings G.S., Dobertin M., A comparison of distance-dependent competition measures for height and basal area growth of individual conifer trees, For. Sci. 38 (1992) 695-720.

[12] Black T.A., Chen J.M., Lee X., Sagar R.M., Characteristics of shortwave and longwave irradiances under a Douglas-fir stand, Can. J. For. Res. 21 (1991) 1020-1028.

[13] Blackburn W.J., Proctor H.T.A., Estimating photosynthetically active radiation from measured solar irradiance, Sol. Energy 31 (1983) 233-234.

[14] Brown M.J., Parker G.G., Canopy light transmittance in a chronosequence of mixed-species deciduous forests, Can. J. For. Res. 28 (1994) 1694-1703.

[15] Brunner A., A light model for spatially explicit forest stand models, For. Ecol. Manage. 107 (1998) 19-46.

[16] Cannell M.G.R., Grace J., Competition for light: detection, measurement, and quantification, Can. J. For. Res. 23 (1993) 1969-1979.

[17] Cannell M.G.R., Sheppard L.J., Milne R., Grace J., Light use efficiency and woody biomass production of poplar and willow, Forestry 61 (1988) 126-136.

[18] Cescatti A., Modelling the radiative transfer in discontinuous canopies of asymmetric crowns. I. Model structure and algorithms, Ecol. Model. 101 (1997) 263-274.

[19] Comeau P., Measuring light in the forest, Extension note 42, Ministry of Forests Research Program, British Columbia, 2000, 7 p.

[20] Courbaud B., Comparing light interception with stand basal area for predicting tree growth, Tree Physiol. 20 (2000) 407-414.

[21] Cutini A., The influence of drought and thinning on leaf area index estimates from canopy transmittance method, Ann. Sci. For. 53 (1996) 595-603.

[22] Dai X., Influence of light conditions in canopy gaps on forest regeneration: a new gap light index and its application in a boreal forest in east-central Sweden, For. Ecol. Manage 84 (1996) 187-197.

[23] Ferment A., Picard N., Gourlet-Fleury S., Baraloto C., A comparison of five indirect methods for characterizing the light environment in a tropical forest, Ann. For. Sci. 58 (2001) 877-891. 
[24] Geiger R., The Climate Near the Ground, Harvard University Press, Cambridge, 1965, $612 \mathrm{p}$.

[25] Grace J.C., Jarvis P.G., Norman J.M., Modelling the interception of solar radiation energy in intensively managed stands, N.Z. J. For. Sci. 17 (1987) 193-209.

[26] Granier A., Étude des relations entre la section du bois d'aubier et la masse foliaire chez le Douglas (Pseudotsuga menziensii (Mirb.) Franco), Ann. Sci. For. 48 (1991) 503-512.

[27] Guitton J.L., Ruchaud F., Conséquences écologiques de l'éclaircie des peuplements de résineux, Informations-Forêt 1 , fiche $\mathrm{n}^{\circ} 523$, 1996, 6 p.

[28] Hale S.E., Light regime beneath Sitka spruce plantations in northern Britain: preliminary results, For. Ecol. Manage. 151 (2001) $61-66$.

[29] Hale S.E., The effect of thinning intensity on the below-canopy light environment in a Sitka spruce plantation, For. Ecol. Manage. 179 (2003) 341-349.

[30] Houllier F., Bouchon J., Birot Y., Modélisation de la dynamique des peuplements forestiers: état et perspectives, Rev. For. Fr. 63 (1991) 87-107.

[31] Kobe R.K., Pacala S.W., Silander J.A. Jr., Canham C.D., Juvenile tree survivorship as a component of shade tolerance, Ecol. Appl. 5 (1995) 517-532.

[32] Kozlowski T.T., Kramer P.J., Pallardy S.G. (Eds.), The physiological ecology of woody plants, Academic Press, San Diego, CA, $1991,657 \mathrm{p}$

[33] Kuusipalo J., On the use of tree stand parameters in estimating light conditions below the canopy, Silva Fenn. 19 (1985) 185-196.

[34] Lieffers V.J., Messier C., Stadt K.J., Gendron F., Comeau P.G., Predicting and managing light in the understorey of boreal forests, Can. J. For. Res. 29 (1999) 796-811.

[35] Long J.N., Smith F.W., Leaf area - sapwood area relations of lodgepole pine as influenced by stand density and index, Can. J. For. Res. 18 (1988) 247-250.

[36] Medhurst J.L., Beadle C.L., Crown structure and leaf area index development in thinned and unthinned Eucalyptus nitens plantations, Tree Physiol. 21 (2001) 989-999.

[37] Meloni S., Sinoquet H., Assessment of the spatial distribution of light transmitted below young trees in an agroforestry system, Ann. Sci. For. 54 (1997) 313-333.

[38] Messier C., Nikinmaa E., Effects of light availability and sapling size on the growth, biomass allocation, and crown morphology of understory sugar maple, yellow birch, and beech, Écoscience 7 (2000) 345-356.

[39] Monsi M., Saeki T., Über den Lichtfaktor in den Planzengesellschaften und seine Bedeutung für die Stoffproduction, Soc. Jap. J. Bot. 14 (1953) 22-52.

[40] Monteith J.L., Solar radiation and productivity in tropical ecosystems, J. Appl. Ecol. 9 (1972) 747-766.

[41] Mungai D.N., Stigter C.J., Coulson C.L., Ng'etich W.K., Muniafu M.M., Kainkwa R.M.R., Measuring solar radiation transmission in tropical agriculture using tube solarimeters; a warning, Agric. For. Meteorol. 86 (1997) 235-243.

[42] Nilson T., A theoretical analysis of the frequency of gaps in plant stands, Agric. Meteorol. 8 (1971) 25-38.

[43] Oker-Blom P., Pukkala T., Kuuluvainen T., Relationship between radiation interception and photosynthesis in forest canopies: effect of stand structure ad latitude, Ecol. Model. 40 (1989) 73-87.

[44] Page L.M., Cameron A.D., Clarke G.C., Influence of overstorey basal area on density and growth of advance regeneration of Sitka spruce in variably thinned stands, For. Ecol. Manage. 151 (2001) $25-35$.

[45] Parker G.G., Davis M.M., Moon Chapotin S., Canopy light transmittance in Douglas-fir-western hemlock stands, Tree Physiol. 22 (2002) 147-157.

[46] Pauwels D., Lejeune P., Balandier P., Rondeux J., A silvicultural decision support system for pure larch stands: helping managers to meet their goals, in: Pâques L.E. (Ed.), "Improvement of larch (Larix sp.) for better growth, stem form and wood quality", 2002/
00/16-21, Gap, Auvergne and Limousin, (FRA), INRA-Cemagref, 2002, pp. 340-349.

[47] Porté A., Bosc A., Champion I., Lousteau D., Estimating the foliage area of Maritime pine (Pinus pinaster Aït.) branches and crowns with application to modeling the foliage area distribution in the crown, Ann. For. Sci. 57 (2000) 73-86.

[48] Roberts S.D., Long J.N., Production efficiency of Abies lasiocarpa: influence of vertical distribution of leaf area, Can. J. For. Res. 22 (1992) 1230-1234.

[49] Roberts S.D., Long J.N., Smith F.W., Canopy stratification and leaf area efficiency: a conceptualization, For. Ecol. Manage. 60 (1993) $143-156$.

[50] Ross M.S., Flanagan L.B., La Roi G.H., Seasonal and successional changes in light quality and quantity in the understory of boreal forest ecosystems, Can. J. Bot. 66 (1986) 2792-2799.

[51] Ruchaud F., Nicolaïdes O., Jouvie R., Modélisation de l'éclairement au sol dans des peuplements de résineux : proposition de sylvicultures développant la richesse spécifique du sous-bois ou la production herbacée, Rapport interne, Cemagref, Clermont-Ferrand, France.

[52] Sampson D.A., Smith F.W., Influence of canopy architecture on light penetration in lodgepole pine (Pinus contorta var. latifolia) forests, Agric. For. Meteorol. 64 (1993) 63-79.

[53] SAS Institute Inc., SAS/STAT Software Version 8 of the SAS System for Windows, 2000, Cary, NC: SAS Institute Inc.

[54] Sattin M., Milne R., Deans J.D., Jarvis P.G., Radiation interception measurement in poplar: sample size and comparison between tube solarimeters and quantum sensors, Agric. For. Meteorol. 85 (1997) 209-216.

[55] Shinozaki K., Yoda K., Hozumi K., Kira T., A quantitative analysis of plant form - The pipe model theory. I. Basic analysis, Jap. J. Ecol. 14 (1964) 97-105.

[56] Sinoquet H., Le Roux X., Short term interactions between tree foliage and the aerial environment: an overview of modeling approaches available for the structure-function models, Ann. For. Sci. 57 (2000) 477-496.

[57] Smith H., Plant architecture and light signals, in: Marshall B., Roberts J.A. (Eds.), Leaf development and canopy growth, Sheffield Academic Press Ltd, CRC Press, 2000, pp. 118-144.

[58] Smith N.J., Predicting radiation attenuation in stands of Douglas-fir (Pseudotsuga menziesii), For. Sci. 37 (1991) 1213-1223.

[59] Smith N.J., Estimating leaf area index and light extinction coefficient in stands of Douglas-fir (Pseudotsuga menziesii), Can. J. For. Res. 23 (1993) 317-321.

[60] Toutain F., Les humus forestiers: structure et mode de fonctionnement, Rev. For. Fr. 32 (1981) 449-479.

[61] Turner D.P., Acker S.A., Means J.E., Garman S.L., Assessing alternative allometric algorithms for estimating leaf area of Douglas-fir trees and stands, For. Ecol. Manage. 126 (2000) 61-76.

[62] Usoltsev V.A., Hoffmann C.W., A preliminary crown biomass table for even-aged Picea abies stands in Switzerland, Forestry 70 (1997) 103-112.

[63] Varlet-Grancher C., Chartier M., Gosse G., Bonhomme R., Rayonnement utile pour la photosynthèse des végétaux en conditions naturelles : caractérisation et variations, Acta Oecol. Oecol. Plant. 16 (1981) 189-202.

[64] Varlet-Grancher C., Gosse G., Chartier M., Sinoquet H., Bonhomme R., Allirand J.M., Mise au point : rayonnement solaire absorbé ou intercepté par le couvert végétal, Agronomie 9 (1989) 29-43.

[65] Vertessy R.A., Benyon R.G., O'Sullivan S.K., Gribben P.R., Relationships between stem diameter, sapwood area, leaf area and transpiration in a young mountain ash forest, Tree Physiol. 15 (1995) 559-567.

[66] Waring R.H., Schoeder P.E., Oren R., Application of the pipe model theory to predict canopy leaf area, Can. J. For Res. 12 (1982) $556-560$.

[67] West P.W., Model of above-ground assimilate partitioning and growth of individual trees in even-aged forest monoculture, J. Theor. Biol. 161 (1993) 369-394. 